\title{
Prodrugs eller prodruger?
}

\author{
Prodrug er en substans som i seg selv ikke er virksom, men som i kroppen omdannes til et aktivt legemiddel. \\ Hva bør det hete på norsk?
}

Velkjente eksempler på denne typen midler er kodein som omdannes i kroppen til morfin, levodopa til dopamin og prednison til prednisolon.

Ordet prodrug er registrert i engelsk fra slutten av 1960-årene (1-3). Etter hvert er det brukt en del også i norsk. Det er registrert over 20 ganger i Tidsskriftets nettutgave, som omfatter årgangene fra 2000, og er også oppført i de tre store norske medisinske ordbøkene (4-6). I det digitale Nasjonalbiblioteket er ordet første gang registrert i begynnelsen av 1980-årene (7). Den gang ble det skrevet med bindestrek: pro-drug (8). At det ennå kan oppfattes som fremmed på norsk, fremgår i nyere lærebøker der man skriver «såkalte «prodrugs»»» (9).

Hva kan være et norsk avløserord? Blant forslagene er promedisin, prolegemiddel eller førlegemiddel. De er noe lengre enn prodrug, men mer entydige. Førdroge eller før-medikament er også foreslått. Premedisin eller pre-medikament er imidlertid ikke så gode på grunn av ordlikheten med premedikasjon, som er betegnelsen på legemidler som gis før en operasjon eller annen prosedyre. Her er dessuten ikke poenget at det gis før (pro) noe, men at det er i en førform, før det skal bli et aktivt medikament. På engelsk brukes precursor synonymt med prodrug, altså forløper på norsk.

\section{Drug}

Drug er flertydig på engelsk, det kan bety både legemiddel og narkotisk stoff. Ved å importere ordet følger nok tvetydigheten med på lasset, slik drug dependence kan bety både medikamentavhengighet og stoffavhengighet. Noen velger å presisere i form av illicit drugs når det gjelder rusmidlene og skriver om til pharmaceutical products, pharmaceutical agents etc. når det gjelder legemidler, men det blir jo unektelig tyngre. Som en kuriositet kan nevnes at drug er lånt inn i engelsk fra fransk drogue, som igjen har lånt ordet fra mellomnederlandsk drog med betydningen tørr. Så ordet har gjort en lang rundreise.

Både drug (stimulerende middel) og drugge (påvirke med narkotika) er oppført i Tanums store rettskrivningsordbok (10), men det betyr ikke at ordene er gode som fagord, bare at de er registrert i bruk.

En løsning kunne være å norvagisere skrivemåten til $\operatorname{drøg}(\mathrm{g})$, men det ville nok lide samme negative skjebne som pøbb (for pub) som Språkrådet foreslo i 1990-årene.

\section{Kjønn og flertall}

Skal det så hete en eller et drug? Mønsteret i moderne norsk er at slike innlånte ord blir maskuline, altså en drug. Da vil bøyningen bli en prodrug, prodrugen, prodruger, prodrugene. Jeg tror neppe noen vil si «en prodrugs». Det finnes imidlertid en del innlånte engelske ord som i norsk opptrer med flertallsform i entall og dobbelt flertallsform, for eksempel en kaps - kapsen - kapser kapsene.

\section{Konklusjon}

Prodrug må anses som innarbeidet i norsk fagspråk. Forsøk på en norsk avløserterm vil neppe føre frem nå. Trolig bør det bøyes som hankjønnsord, altså prodrug, prodrugen, prodruger, prodrugene.

Jeg takker Gruppe for norsk medisinsk fagspråk og Olav Spigset for nyttige kommentarer.

\section{Erlend Hem}

erlend.hem@medisin.uio.no

Erlend Hem (f. 1970) er dr.med., fagsjef i Klinikk psykisk helse og avhengighet, Oslo universitetssykehus, og redaktør for Tidsskriftets språkspalte.
Litteratur

1. Prodrug. I: PubMed. www.ncbi.nlm.nih.gov/ pubmed/?term=prodrug (10.10.2016)

2. Prodrug. I: Oxford English Dictionary. www.oed.com/view/Entry/241449 (29.5.2016).

3. Dittert LW, Caldwell HC, Adams HJ et al. Acetaminophen prodrugs. I. Synthesis, physicochemical properties, and analgesic activity. J Pharm Sci 1968; 57: 774-80

4. Prodrug. I: Øyri A. Norsk medisinsk ordbok. 9. utg Oslo: Samlaget, 2011: 879

5. Prodrug. I: Nylenna M, red. Medisinsk ordbok. 7. utg. Oslo: Kunnskapsforlaget, 2009: 377.

6. Prodrug. I: Lindskog BI. Gyldendals store medisinske ordbok. 2. utg. Oslo: Gyldendal, 2003: 442-3.

7. Prodrug. I: bokhylla.no. www.nb.no/nbsok/ search?action=search\&searchString=prodrug (10.10.2016)

8. Tønnessen TI. Smerter og andre symptomer hos kreftpasienter: diagnose og behandling. Oslo: Universitetsforlaget, 1983: 44. www.nb.no/nbsok/nb/ 72546f577885d0693fba39a037ff0a0e?index=1\#46 (10.10.2016)

9. Nordeng H, Spigset O, red. Legemidler og bruken av dem. 2. utg. Oslo: Gyldendal akademisk, 2013: 61

10. Drug, drugge. I: Wangensteen B, red. Tanums store rettskrivningsordbok. 10. utg. Oslo: Kunnskapsforlaget, 2015: 224. 